\title{
Non-clinical toxicological evaluation of the ethanolic extract from Zornia brasiliensis Vogel (Fabaceae)
}

Tatianne Batista ${ }^{1}$, Renata Abrantes ${ }^{1}$, Aline Xavier ${ }^{1}$, João Carlos Pita ${ }^{1}$, Monalisa Brito ${ }^{1}$, Adriano Alves ${ }^{1}$, Anne Dayse ${ }^{1}$, Yuri Nascimento $^{1}$, Sócrates Santos ${ }^{1}$, Josean Tavares ${ }^{1,2}$, Marcelo Silva ${ }^{1,2}$, Marianna Sobral ${ }^{1,2^{*}}$

${ }^{1}$ Post Graduation Program in Bioactive Natural and Synthetic Products, Federal University of Paraíba, 58051-970 João Pessoa, PB, Brazil.

${ }^{2}$ Department of Pharmaceutical Sciences, Federal University of Paraíba, 58051-970 João Pessoa, PB, Brazil.

\begin{tabular}{l}
\hline ARTICLE INFO \\
\hline Received on: 04/05/2020 \\
Accepted on: $10 / 12 / 2020$ \\
Available online: $05 / 04 / 2021$
\end{tabular}

Key words:

Acute toxicity, repeated-dose toxicity, genotoxicity. Zornia.

\begin{abstract}
Zornia brasiliensis Vogel, Fabaceae, is used to treat venereal diseases and as diuretic in Brazilian northeast folk medicine. Herein, the toxicity profile of ethanolic extract from Z. brasiliensis aerial parts (ZBEE) was evaluated. Hemolysis assay was used to evaluate the in vitro toxicity, where as in vivo acute and repeated-dose (28 days) toxicity tests were performed on adult Swiss albino mice. Micronucleus test was used to evaluate genotoxicity. The concentration of ZBEE that produced $50 \%$ hemolysis $\left(\mathrm{HC}_{50}\right)$ was $1,954 \mu \mathrm{g} / \mathrm{ml}$, indicating low cytotoxicity. In acute toxicity assay, no deaths or behavioural changes in mice treated with 2,000 mg/kg ZBEE were recorded. Regarding the repeated-dose evaluation, after 28 days of treatment with ZBEE $(250,500$, and $1,000 \mathrm{mg} / \mathrm{kg}$, oral gavage), weak toxicity signs on biochemical, haematological, and neurological parameters were observed, especially for the highest dose tested. ZBEE $(2,000 \mathrm{mg} / \mathrm{kg})$ did not induce an increase in micronucleated erythrocytes number, suggesting no genotoxicity. In summary, ZBEE showed low nonclinical toxicity. These data support its safe use in the folk medicine and further studies to characterize the pharmacological activities of this medicinal plant.
\end{abstract}

\section{INTRODUCTION}

Herbal medicine has been considered as an alternative form for treatment against several diseases. However, despite many people consider products obtained from nature safe, literature data have shown toxicological effects for medicinal plants. Then, toxicological studies should be done to ensure the safety of herbal drugs (Da Silva et al., 2018; Kahaliw et al., 2018).

Zornia brasiliensis Vogel (Fabaceae), popularly known as "urinária," "urinana," and "carrapicho," is used in Brazilian northeast folk medicine to treat venereal diseases and as diuretic (Agra et al., 2008). Literature data showed antioxidant and cytotoxic activities on Artemia salina larvae for the methanolic extract from Z. brasiliensis aerial parts (ZBEE) (David et al., 2007). In addition, antinociceptive activity of 7 -methoxyflavone, obtained

"Corresponding Author

Marianna Sobral, Jardim Cidade Universitária, S N, João Pessoa, Brazil; Federal University of Paraíba, João Pessoa, PB, Brazil.

E-mail:mariannavbs@gmail.com from Z. brasiliensis (Da Silva et al., 2013), and antitumor effect for the leaf volatile oil were recorded (Costa et al., 2015). Recently, the isolation of one previously undescribed C-glycosylated dihydrochalcone (zornioside), which was selectively cytotoxic for HL60 leukemia cells, and the presence of saponins in this species were reported (Nascimento et al., 2018, 2019).

Nevertheless, despite the popular use for medicinal purposes, there are no toxicological reports in the literature for $Z$. brasiliensis. Herein, we evaluated the acute and repeated-dose toxicity of Z. brasiliensis in order to provide scientific data to support its safe use and further pharmacological tests.

\section{MATERIALS AND METHODS}

\section{Vegetable sample}

The aerial parts (composed of stem, leaves, and inflorescence) of Z. brasiliensis Vogel (Fabaceae) were collected in June (winter) 2016, in the city of Serra Branca $\left(07^{\circ} 29^{\prime} 46^{\prime \prime} \mathrm{S}\right.$ and $36^{\circ} 44^{\prime} 36^{\prime \prime} \mathrm{W}$, altitude: reaching $712 \mathrm{~m}$ elevation), located in the state of Paraíba, Brazil. An exsiccata is deposited in the Herbarium Arruda Câmara, in Campus I of the State University 
of Paraíba (UEPB), code 1,862. This study was registered in the National Management System of Genetic Patrimony and Associated Traditional Knowledge (SISGEN, Curitiba, Brazil) with registration number ADD107E. Ethanolic extract from ZBEE was obtained from the plant material $(5 \mathrm{~kg})$ subjected to extraction with $95 \%$ ethanol by maceration $[1: 3, \mathrm{w}(\mathrm{kg}) / \mathrm{v}(\mathrm{l})]$ at room temperature for 72 hours; this process was repeated four times. The final extraction yield was $11 \%$ (Nascimento et al., 2018).

\section{Quantification by high-performance liquid chromatography coupled to a diode array detector (HPLC-DAD)}

The substances 7-methoxyflavone and 5,7-dimethoxyflavone (Nascimento et al., 2018) were quantified in the macerated crude ethanolic extract, and they were considered as markers of the
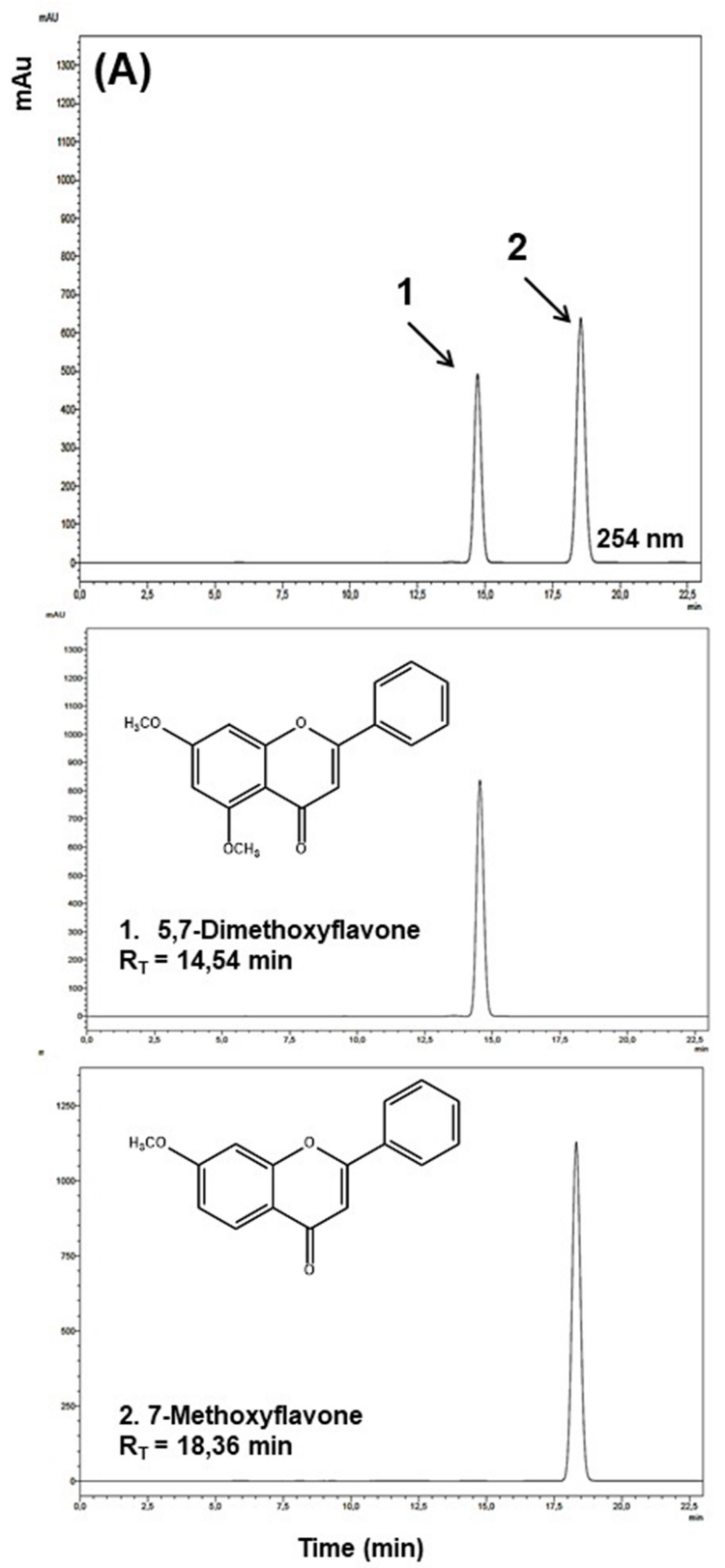

extract. This quantification was performed by HPLC-DAD. For this, it was used as stationary phase a reverse-phase Kromasil ${ }^{\circledR} \mathrm{C} 4$ column $(250 \mathrm{~mm} \times 4.6 \mathrm{~mm}$ ID, $3.5 \mu \mathrm{m}$ filled with particles $)$ with a Kromasil ${ }^{\circledR} \mathrm{C} 4$ precolumn $(4.6 \mathrm{~mm}$ ID $\times 3.0 \mathrm{~mm}, 3.5 \mu \mathrm{m}$ filled with particles) and as mobile phase the solvents: water $(0.1 \%$ formic acid) and acetonitrile $(1: 1, v / v)$ were used as the mobile phase in isocratic mode for 23 minutes, at a flow rate of $0.45 \mathrm{ml} / \mathrm{minutes}$, the temperature of $40^{\circ} \mathrm{C}$, and the detection was performed at 254 $\mathrm{nm}$. The content of 7-methoxyflavone and 5,7-dimethoxyflavone in the $Z$. brasiliensis extract was 146.54 and $74.45 \mathrm{mg} / \mathrm{g}$ extract, respectively (Fig. 1).

\section{Animals}

Adult Swiss albino mice (Mus musculus), female and male (28-32 g), obtained from the Dr. Thomas George Bioterium
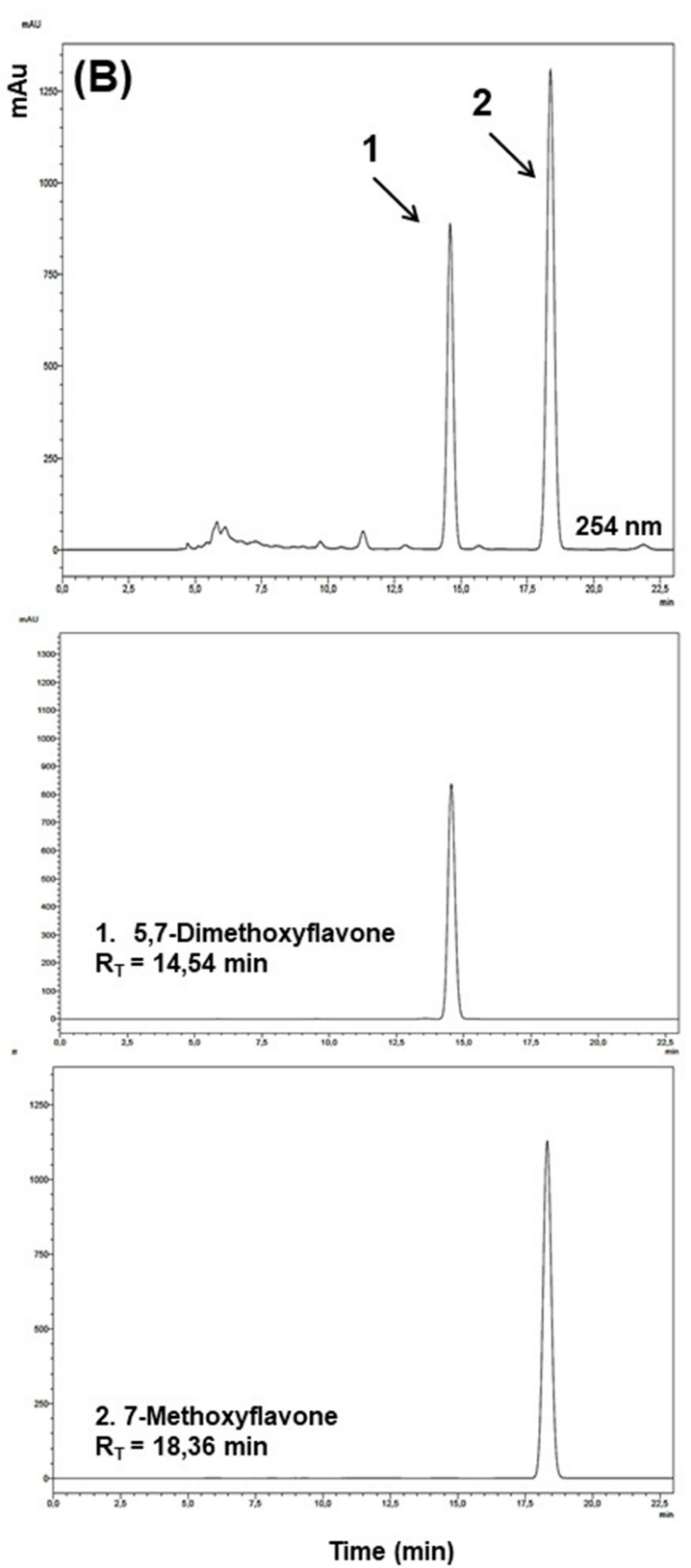

Figure 1. High-HPLC-DAD analysis of extract of Zornia brasiliensis. (A) Standard mixture (70 and $150 \mu \mathrm{g} / \mathrm{ml}$ of 5,7-dimethoxyflavone and 7-methoxyflavone, respectively). (B) Extract sample (2 mg/ml). RT = retention time. 
Research Institute in Drugs and Medicines/Federal UEPB, Paraíba, Brazil, were used. Animals were randomly selected and separated by gender in rodent cages in a controlled environment (12/12 hours light-dark cycle, $24^{\circ} \mathrm{C} \pm 1{ }^{\circ} \mathrm{C}, 55 \%$ relative humidity) with food and water ad libitum. Animals were housed in groups of 6 . The total number of animals/group changed according to the method ( $n=6 /$ gender/group for acute assay, $n=10 /$ gender/group for repeated-dose assay, and $n=6$ males for micronucleus assay). All the study was approved by the Animal Ethics Committee of the Federal UEPB in December 2015 (CEUA/UFPB number 0701/14).

\section{Hemolysis test}

Mouse erythrocytes were used to evaluate the hemolytic effect of ZBEE (Kang et al., 2009). Swiss mice were anesthetized with sodium thiopental, $40 \mathrm{mg} / \mathrm{kg}$, intraperitoneally (i.p.), and fresh blood was collected from the orbital plexus to obtain the erythrocytes. To avoid coagulation, the needle was heparinized (sodium heparin). Then, erythrocytes were suspended in phosphate-buffered saline (PBS) to make a $1 \%(v / v)$ solution, which was incubated with various concentrations of ZBEE $(0-$ $7,500 \mu \mathrm{g} / \mathrm{ml})$ dissolved in cremophor $(1.5 \%, v / v$, in PBS). The plates were shaken for 60 minutes. After centrifugation and removal of the supernatant, Triton X-100 solution $(0.1 \%)$ was added $(200 \mu \mathrm{l} /$ well $)$ and the plate was shaken. The hemolysis induced by Triton X-100 (0.1\%) was determined at $415 \mathrm{~nm}$ and served as the reverse test to set the $\mathrm{HC}_{50}$ (concentration that produces $50 \%$ hemolysis) of ZBEE. The positive and negative controls were made (100\% and $0 \%$ hemolysis, respectively) by incubating erythrocytes with $0.1 \%$ Triton X-100 in PBS and $1.5 \%$ of cremophor in PBS, respectively.

\section{Acute and repeated-dose toxicity assays}

The study of acute and repeated-dose toxicity of ZBEE was carried out in accordance with the Brazilian Health Surveillance Agency (Anvisa) regulations (Brazil, Ministry of Health, 2013).

For acute toxicity assay, mice ( $n=6 /$ gender/group) received a single dose of $2,000 \mathrm{mg} / \mathrm{kg} \mathrm{ZBEE}$ by oral gavage, and the control group was treated with the vehicle (Tween 80 at $12 \%(v / v)$ in saline). The activity on the Central Nervous System or Autonomic Nervous System was investigated at 0, 15, 30, and 60 minutes, 4 hours, and daily for 14 days. Food and water consumption was recorded daily, and the animal's weight was recorded at the beginning and at the end of treatment. The dose that killed $50 \%$ of animals $\left(\mathrm{LD}_{50}\right)$ was estimated.

For repeated-dose toxicity test, Swiss mice $(n=10$ / gender/group), after 3 hours fasting, received ZBEE by oral gavage $(250,500$, or $1,000 \mathrm{mg} / \mathrm{kg})$, for 28 days, and the control group was treated with the vehicle [Tween 80 at $12 \%(v / v)$ in saline] under the same conditions. During the experiment, water and food intake and weight evolution were observed. On the day before the first administration (Basal) and the 14th and 28th days of administration, exploratory activity (open-field test) and motor activity (rotarod test) were evaluated.

One day after the last treatment, orbital plexus blood samples from all animals under anesthesia [sodium thiopental, 40 $\mathrm{mg} / \mathrm{kg}$, intraperitoneally (i.p).)] were obtained (Diehl et al., 2001).
To avoid coagulation, the needle was heparinized (sodium heparin). Urea and creatinine levels and the alanine aminotransferase (ALT) and aspartate aminotransferase (AST) activities were quantified in serum samples using respective kits (Labtest ${ }^{\circledR}$, Brazil) according to the manufacturer's instructions in Cobas Mira Plus ${ }^{\circledR}$. The hematological analysis was performed using heparinized whole blood to determine the following parameters: hemoglobin $(\mathrm{Hb})$ level, red blood cell (RBC) count, and hematocrit (Hct), and the red cell indices mean corpuscular volume, mean corpuscular hemoglobin, mean corpuscular hemoglobin concentration, and total and differential leukocyte counts using a Hematoclin 2.8 Vet (Bioclin $\left({ }^{\circledR}\right)$. Then, after euthanasia by cervical dislocation, livers were removed and fixed in $10 \%(v / v)$ formaldehyde. Portions of the livers were cut into sections of $3 \mu \mathrm{m}$, stained with Masson's trichrome, and subjected to histopathological analysis.

\section{Micronucleus assay}

For the micronucleus assay, mice ( $n=6$ males/group) were subjected to a single oral gavage dose of $2,000 \mathrm{mg} / \mathrm{kg}$ ZBEE. Positive and negative control groups (cyclophosphamide, $50 \mathrm{mg}$ / $\mathrm{kg}$ i.p. and Tween 80 at $12 \%(v / v)$ in saline, respectively) were added. After 48 hours treatment, blood extensions were made with peripheral blood samples collected from the tail $(10 \mu \mathrm{l})$. After drying, the slides were stained with panoptic staining for further analysis under an optical microscope. Two thousand erythrocytes were counted in three blood extensions for each animal, and the number of micronucleated erythrocytes was recorded (OECD, 2016).

\section{Statistical analysis}

Data are presented as mean \pm SEM. Statistical analysis was performed using analysis of variance (ANOVA) one-way followed by Tukey's test $(p<0.05)$. For the comparison between the two groups, the Student $t$-test was used $(p<0.05)$.

\section{RESULTS AND DISCUSSION}

Toxicity assessment is an essential step in the development of new synthetic or natural medicines. Moreover, toxicity tests are necessary to ensure the safe use of medicinal plants in the folk medicine. Considering the popular use of $Z$. brasiliensis for medicinal purposes, in this study, we evaluated the acute and repeated-dose toxicity, besides the hemolytic and genotoxic effects.

The hemolysis test is an important assay used to assess the toxicity of new drugs. Considering that erythrocytes are cells without a nucleus and organelles, this assay aims to evaluate changes in red cell membranes. Then, erythrocytes of mammals are a useful model to study the cytotoxicity of new natural or synthetic drugs by cellular damage measure (Pagano and Faggio, 2015). Literature data have shown that $\mathrm{CH} 50$ values higher than $1,250 \mu \mathrm{g} / \mathrm{ml}$ suggest no hemolytic activity for plants (Dos SantosJúnior et al., 2010). Herein, ZBEE-induced hemolysis only on high concentrations, with HC50 value of $1954(1,840-2,074) \mu \mathrm{g} /$ $\mathrm{ml}$, indicating no cytotoxicity to erythrocytes.

For ZBEE, on the acute study, no toxicity signs or deaths were observed after treatment $(2,000 \mathrm{mg} / \mathrm{kg})$. Then, $\mathrm{LD}_{50}$ value is higher than $2,000 \mathrm{mg} / \mathrm{kg}$. There was a decrease on food intake for males; however, this effect was not accompanied by changes in the 
final weight of the ZBEE treated animals (Table 1). Then, these results together suggest weak acute toxicity for ZBEE.

Repeated-dose toxicity studies aim to characterize the toxicological profile of a new drug by repeated administration. Among the parameters evaluated on that assay are mortality, behavioral parameters, water and food intake, body weight, and clinical pathology (biochemical, hematological, and histopathological parameters) (ANVISA, 2013; OECD, 2008). For ZBEE, no death was recorded on 28-days assay. A decrease in food and water intake was observed. However, similar to acute assay, these effects did not induce any change in the final weight of the ZBEE treated animals (Table 2).

To evaluate the neurological effects of ZBEE, rotarod and open-field tests were used. In rodents, rotarod assay has been used to assess the motor deficits (Miyanishi et al., 2019), and the open-field test is employed to evaluate anxiety, locomotion, and stereotypical behaviors, such as grooming and rearing (Prut and Belzung, 2003). During the repeated-dose assay, no effect on rotarod assay was observed for ZBEE treated animals (Table 3), suggesting that ZBEE did not induce changes in psychomotor coordination. On open-field assay, no changes were observed in the number of rearing and grooming behaviors (Table 4). For female mice treated with $1,000 \mathrm{mg} / \mathrm{kg}$ ZBEE, there was an increase in ambulation $(56.7 \pm 4.7 ; p<0.05)$, only at the end of treatment (Table 4). Nevertheless, only this isolated data does not suggest a behavioral change. Instead, the neurological evaluation for ZBEE suggested no motor and behavioral changes.

Urea and creatinine serum levels are conventional circulating biomarkers for detecting nephrotoxicity. In addition, drug-induced liver injury, which is caused by drugs and herbal or dietary supplements, is evaluated using specific serum biomarkers, as ALT and AST activities (ANVISA, 2013; OECD, 2008). On biochemical evaluation, no change in serum urea was observed after ZBEE treatment (Tables 5 and 6). For creatinine levels, a decrease for all female mice groups was observed $(p<0.05)$ (Table 6). However, despite these changes, the serum levels for

Table 1. Effects of ZBEE on feed and water consumption and weight evolution of mice subjected to a single dose (2000 mg/kg, v.o.).

\begin{tabular}{ccccccc}
\hline Groups & Dose $(\mathbf{m g} / \mathbf{k g})$ & Sex & Feed intake $(\mathbf{g})$ & Water intake $(\mathbf{m l})$ & Starting weight $(\mathbf{g})$ & Final weight $(\mathbf{g})$ \\
\hline \multirow{2}{*}{ Control } & - & M & $39.8 \pm 1.0$ & $50.9 \pm 2.7$ & $30.6 \pm 0.5$ & $35.5 \pm 1.5$ \\
& & F & $37.8 \pm 1.4$ & $48.9 \pm 1.9$ & $28.3 \pm 0.2$ & $32.0 \pm 0.7$ \\
\multirow{2}{*}{ ZBEE } & 2,000 & M & $24.7 \pm 1.1^{\text {a }}$ & $45.9 \pm 2.8$ & $30.2 \pm 1.0$ & $33.8 \pm 2.4$ \\
& & F & $40.3 \pm 1.3$ & $55.4 \pm 3.5$ & $28.4 \pm 0.4$ \\
\hline
\end{tabular}

Data are expressed as the mean \pm SEM from six animals/gender/group analyzed by Student $t$-test.

asignificantly different from the control group $(p<0.05)$.

Table 2. Effects of ZBEE on feed and water consumption and weight evolution of mice subjected to repeated dose (28 days, v.o.)

\begin{tabular}{|c|c|c|c|c|c|c|}
\hline Groups & Dose (mg/kg) & Sex & Feed intake(g) & Water intake $(\mathrm{ml})$ & Startingweight (g) & Finalweight (g) \\
\hline \multirow{2}{*}{ Control } & \multirow{2}{*}{ - } & $\mathrm{M}$ & $40.6 \pm 1.3$ & $54.0 \pm 2.1$ & $29.6 \pm 0.9$ & $37.7 \pm 1.2$ \\
\hline & & $\mathrm{F}$ & $45.6 \pm 1.7$ & $43.8 \pm 1.0$ & $27.0 \pm 0.6$ & $33.2 \pm 0.7$ \\
\hline \multirow{2}{*}{ ZBEE } & \multirow{2}{*}{250} & M & $43.0 \pm 1.5$ & $55.1 \pm 2.2$ & $29.7 \pm 0.6$ & $38.4 \pm 1.1$ \\
\hline & & $\mathrm{F}$ & $27.1 \pm 0.8^{\mathrm{a}}$ & $41.5 \pm 1.5$ & $25.4 \pm 0.7$ & $32.4 \pm 1.3$ \\
\hline \multirow{2}{*}{ ZBEE } & \multirow{2}{*}{500} & $\mathrm{M}$ & $32.4 \pm 1.6^{\mathrm{a}}$ & $46.6 \pm 1.4^{\mathrm{a}}$ & $26.9 \pm 0.8$ & $41.7 \pm 1.3$ \\
\hline & & $\mathrm{F}$ & $30.9 \pm 0.9^{\mathrm{a}}$ & $42.9 \pm 1.3$ & $25.4 \pm 0.5$ & $36.2 \pm 0.6$ \\
\hline \multirow{2}{*}{ ZBEE } & \multirow{2}{*}{1,000} & M & $29.7 \pm 1.0^{\mathrm{a}}$ & $45.2 \pm 1.5^{\mathrm{a}}$ & $28.3 \pm 0.7$ & $39.2 \pm 1.2$ \\
\hline & & $\mathrm{F}$ & $39.4 \pm 1.3^{\mathrm{a}}$ & $51.8 \pm 1.8^{\mathrm{a}}$ & $25.6 \pm 0.3$ & $35.8 \pm 0.8$ \\
\hline
\end{tabular}

Data are expressed as mean \pm SEM from ten animals/gender/group analyzed by ANOVA followed by Tukey test.

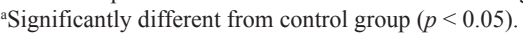

Table 3. Effects of ZBEE on psychomotor coordination by rotarod treadmill apparatus of mice subjected to repeated dose (28 days, v.o.).

\begin{tabular}{|c|c|c|c|c|c|}
\hline \multirow{2}{*}{ Groups } & \multirow{2}{*}{ Dose (mg/kg) } & \multirow{2}{*}{ Sex } & \multicolumn{3}{|c|}{ Time spent on rotarod apparatus (s) } \\
\hline & & & Basal & 14 days & 28 days \\
\hline \multirow{2}{*}{ Control } & \multirow{2}{*}{-} & $\mathrm{M}$ & $155.6 \pm 15.6$ & $171.6 \pm 6.2$ & $161.5 \pm 12.4$ \\
\hline & & $\mathrm{F}$ & $168.9 \pm 4.5$ & $168.4 \pm 5.6$ & $178.6 \pm 1.4$ \\
\hline \multirow{2}{*}{ ZBEE } & \multirow{2}{*}{250} & $\mathrm{M}$ & $166.0 \pm 9.1$ & $167.4 \pm 10.2$ & $176.8 \pm 2.2$ \\
\hline & & F & $165.8 \pm 4.5$ & $173.6 \pm 2.6$ & $172.4 \pm 4.1$ \\
\hline \multirow{2}{*}{ ZBEE } & \multirow{2}{*}{500} & M & $164.6 \pm 9.6$ & $153.4 \pm 6.0$ & $174.8 \pm 5.1$ \\
\hline & & F & $160.6 \pm 9.6$ & $161.1 \pm 7.4$ & $173.0 \pm 3.4$ \\
\hline \multirow{2}{*}{ ZBEE } & \multirow{2}{*}{1,000} & M & $166.6 \pm 6.3$ & $164.5 \pm 12.3$ & $170.9 \pm 5.1$ \\
\hline & & $\mathrm{F}$ & $151.8 \pm 9.5$ & $161.1 \pm 8.2$ & $165.2 \pm 10.6$ \\
\hline
\end{tabular}

Data are expressed as mean \pm SEM from ten animals/gender/group analyzed by ANOVA followed by Tukey test. 
Table 4. Effects of ZBEE on open-field behavior test on mice subjected to repeated dose (28 days, v.o.).

\begin{tabular}{|c|c|c|c|c|c|}
\hline \multirow{2}{*}{ Groups } & \multirow{2}{*}{ Dose $(\mathrm{mg} / \mathrm{kg})$} & \multirow{2}{*}{ Sex } & \multicolumn{3}{|c|}{ Number of rearing behaviors $\left(\mathrm{n}^{0}\right)$} \\
\hline & & & Basal & 14 days & 28 days \\
\hline \multirow{2}{*}{ Control } & \multirow{2}{*}{-} & $\mathrm{M}$ & $4.5 \pm 1.2$ & $4.0 \pm 2.0$ & $7.3 \pm 1.6$ \\
\hline & & F & $4.6 \pm 1.2$ & $6.8 \pm 17$ & $7.0 \pm 1.3$ \\
\hline \multirow{2}{*}{ ZBEE } & \multirow{2}{*}{250} & M & $2.3 \pm 0.8$ & $8.3 \pm 2.9$ & $3.2 \pm 1.2$ \\
\hline & & $\mathrm{F}$ & $2.5 \pm 1.0$ & $8.3 \pm 4.1$ & $4.1 \pm 1.4$ \\
\hline \multirow{2}{*}{ ZBEE } & \multirow{2}{*}{500} & $\mathrm{M}$ & $5.5 \pm 1.5$ & $7.2 \pm 2.5$ & $3.2 \pm 1.0$ \\
\hline & & $\mathrm{F}$ & $3.2 \pm 1.3$ & $5.6 \pm 2.7$ & $3.5 \pm 1.5$ \\
\hline \multirow{4}{*}{ ZBEE } & \multirow{4}{*}{1,000} & $\mathrm{M}$ & $5.1 \pm 1.9$ & $2.3 \pm 1.1$ & $3.9 \pm 1.4$ \\
\hline & & $\mathrm{F}$ & $2.0 \pm 1.8$ & $5.0 \pm 1.6$ & $6.2 \pm 2.0$ \\
\hline & & & \multicolumn{3}{|c|}{ Grooming (s) } \\
\hline & & & Basal & 14 days & 28 days \\
\hline \multirow{2}{*}{ Control } & \multirow[t]{2}{*}{-} & $\mathrm{M}$ & $16.7 \pm 6.6$ & $11.6 \pm 2.9$ & $7.6 \pm 2.1$ \\
\hline & & $\mathrm{F}$ & $6.9 \pm 2.7$ & $14.3 \pm 2.9$ & $16.0 \pm 5.5$ \\
\hline \multirow{2}{*}{ ZBEE } & \multirow[t]{2}{*}{250} & $\mathrm{M}$ & $18.2 \pm 3.7$ & $16.8 \pm 5.0$ & $7.8 \pm 2.0$ \\
\hline & & $\mathrm{F}$ & $11.0 \pm 2.3$ & $9.1 \pm 2.3$ & $8.6 \pm 2.9$ \\
\hline \multirow{2}{*}{ ZBEE } & \multirow[t]{2}{*}{500} & $\mathrm{M}$ & $16.3 \pm 3.9$ & $10.2 \pm 5.6$ & $9.6 \pm 2.9$ \\
\hline & & $\mathrm{F}$ & $17.3 \pm 5.9$ & $11.5 \pm 2.6$ & $5.3 \pm 1.6$ \\
\hline \multirow{4}{*}{ ZBEE } & \multirow[t]{4}{*}{1,000} & $\mathrm{M}$ & $25.3 \pm 8.8$ & $14.9 \pm 2.9$ & $13.1 \pm 2.4$ \\
\hline & & $\mathrm{F}$ & $11.3 \pm 3.3$ & $16.7 \pm 2.9$ & $11.5 \pm 2.3$ \\
\hline & & & \multicolumn{3}{|c|}{ Ambulance ( $\mathrm{n}^{\circ}$ of quadrants) } \\
\hline & & & Basal & 14 days & 28 days \\
\hline \multirow[t]{2}{*}{ Control } & \multirow[t]{2}{*}{-} & M & $61.4 \pm 4.2$ & $35.4 \pm 4.2$ & $38.0 \pm 5.1$ \\
\hline & & $\mathrm{F}$ & $60.7 \pm 5.6$ & $50.2 \pm 5.3$ & $36.6 \pm 3.4$ \\
\hline \multirow[t]{2}{*}{ ZBEE } & \multirow[t]{2}{*}{250} & $\mathrm{M}$ & $58.0 \pm 7.9$ & $43.8 \pm 3.9$ & $37.0 \pm 1.4$ \\
\hline & & $\mathrm{F}$ & $40.9 \pm 9.5$ & $39.3 \pm 4.9$ & $42.6 \pm 3.8$ \\
\hline \multirow[t]{2}{*}{ ZBEE } & \multirow[t]{2}{*}{500} & $\mathrm{M}$ & $46.7 \pm 3.6$ & $29.2 \pm 5.3$ & $36.3 \pm 2.4$ \\
\hline & & $\mathrm{F}$ & $44.0 \pm 5.6$ & $34.1 \pm 4.5$ & $36.4 \pm 2.9$ \\
\hline \multirow[t]{2}{*}{ ZBEE } & \multirow[t]{2}{*}{1,000} & $\mathrm{M}$ & $42.2 \pm 3.1$ & $35.6 \pm 5.0$ & $40.3 \pm 3.1$ \\
\hline & & $\mathrm{F}$ & $45.4 \pm 7.8$ & $43.9 \pm 4.3$ & $56.7 \pm 4.7^{a}$ \\
\hline
\end{tabular}

Data are expressed as mean \pm SEM from ten animals/gender/group analyzed by ANOVA followed by Tukey test.

${ }^{a}$ Significantly different from control group $(p<0.05)$.

creatinine were within normal parameters for the species (Gad, 2007). There was an increase in AST activity for male mice at $1,000 \mathrm{mg} / \mathrm{kg}$ ZBEE $(243.5 \pm 15.9 \mathrm{U} / \mathrm{l} ; p<0.05)$ (Table 5). For ALT activity, there was an increase for all female mice groups (Table 6) and for $1,000 \mathrm{mg} / \mathrm{kg}$ ZBEE male mice group $(p<0.05)$ (Table 5), suggesting the occurrence of hepatic toxicity. Then, the liver histological examination was performed to investigate this effect. The liver histological analyses of the group subjected to ZBEE $(1,000 \mathrm{mg} / \mathrm{kg})$ were within normal histological limits, as shown in zone 3 (Z3) of the hepatocyte acinus of the liver which presents terminal hepatic venule surrounded by converging hepatocyte plates and sinusoids and in turn presents normal-sized hepatocytes without nuclear changes in addition to normalities without connective tissue (Fig. 2). These findings suggest that the biochemical changes are minor and do not alter the tissue structure.

Hematological parameters analysis is often employed to determine the safety profile, including plant extracts, on the blood constituents. The parameters investigated after ZBEE treatment are important tools in ascertaining the toxicological profile of new drugs (ANVISA, 2013; OECD, 2008). On hematological evaluation, for male mice, an increase in the number of erythrocytes was observed $\left(10.3 \pm 0.310^{6} / \mathrm{mm}^{3}\right.$ and $11.1 \pm 0.410^{6} / \mathrm{mm}^{3} ; p<$ $0.05)$, in hemoglobin concentration $(17.5 \pm 0.5 \mathrm{~g} / \mathrm{dl}$ and $18.7 \pm$ $0.5 \mathrm{~g} / \mathrm{dl} ; p<0.05)$, and in hematocrit $(60.2 \% \pm 1.5 \%$ and $60.3 \%$ $\pm 2.6 \% ; p<0.05)$, for 250 and $500 \mathrm{mg} / \mathrm{kg}$ groups, respectively (Table 5), indicating the increase of RBCs. For female mice groups, a decrease in eosinophils count was observed $(0.4 \pm 0.2$ and $0.0 \pm 0.0$, at 500 and $1,000 \mathrm{mg} / \mathrm{kg}$ ZBEE, respectively; $p<$ $0.05)$, in addition to a decrease in monocytes $(1.3 \pm 0.4 ; p<0.05)$ at $1,000 \mathrm{mg} / \mathrm{kg}$ ZBEE (Table 6). Literature reports have shown that eosinophils, basophils, and monocyte counts are usually very low and variable. Thus, it is improbable to detect toxicological effects on these cell types. Therefore, these isolated changes have no clinical significance.

During the new drugs safety assessment, the genotoxicity is also commonly evaluated. The micronucleus assay has been added in many genotoxic test guidelines of synthetic and natural new drugs (Araldi et al., 2015). Although the trend of the safety 
Table 5. Effects of ZBEE on biochemical and hematological parameters of peripheral blood of male mice subjected to repeated dose (28 days. v.o.).

\begin{tabular}{lcccc}
\hline \multirow{2}{*}{ Parameters } & Control & \multicolumn{3}{c}{ ZBEE $\mathbf{( m g} / \mathbf{k g})$} \\
\cline { 3 - 5 } & & $\mathbf{2 5 0}$ & $\mathbf{5 0 0}$ & $\mathbf{1 , 0 0 0}$ \\
\hline MALE & & & & \\
RBCs $\left(10^{6} / \mathrm{mm}^{3}\right)$ & $9.0 \pm 0.4$ & $10.3 \pm 0.3^{\mathrm{a}}$ & $11.1 \pm 0.4^{\mathrm{a}}$ & $8.3 \pm 0.5$ \\
Hemoglobin $(\mathrm{g} / \mathrm{dl})$ & $13.5 \pm 1.1$ & $17.5 \pm 0.5^{\mathrm{a}}$ & $18.7 \pm 0.5^{\mathrm{a}}$ & $14.3 \pm 0.9$ \\
Hematocrit $(\%)$ & $45.3 \pm 3.5$ & $60.2 \pm 1.5^{\mathrm{a}}$ & $60.3 \pm 2.6^{\mathrm{a}}$ & $54.3 \pm 2.2$ \\
VCM $\left(\mathrm{fm}^{3}\right)$ & $56.4 \pm 1.4$ & $58.0 \pm 1.1$ & $56.2 \pm 2.0$ & $68.3 \pm 6.7$ \\
HCM (pg) & $16.6 \pm 0.5$ & $17.0 \pm 0.3$ & $16.9 \pm 0.5$ & $16.5 \pm 0.2$ \\
CHCM (g/dl) & $29.5 \pm 0.2$ & $29.4 \pm 0.4$ & $30.1 \pm 0.7$ & $23.9 \pm 2.2^{\mathrm{a}}$ \\
Total leukocytes $\left(10^{3} / \mathrm{mm}^{3}\right)$ & $5.1 \pm 0.3$ & $6.5 \pm 0.8$ & $6.0 \pm 0.6$ & $6.8 \pm 0.7$ \\
Lymphocytes & $53.2 \pm 5.2$ & $63.4 \pm 3.4$ & $63.3 \pm 4.6$ & $66.4 \pm 3.9$ \\
Neutrophils & $42.5 \pm 4.9$ & $30.0 \pm 3.1$ & $30.8 \pm 4.2$ & $31.4 \pm 5.0$ \\
Monocytes & $4.3 \pm 0.7$ & $5.7 \pm 0.7$ & $5.7 \pm 0.7$ & $3.57 \pm 0.9$ \\
Eosinophils & $0.0 \pm 0.0$ & $0.4 \pm 0.3$ & $0.5 \pm 0.3$ & $0.0 \pm 0.0$ \\
AST (U/L) & $155.7 \pm 3.0$ & $191.3 \pm 13.7$ & $207.5 \pm 3.5$ & $243.5 \pm 15.9^{\mathrm{a}}$ \\
ALT (U/L) & $36.50 \pm 6.1$ & $56.6 \pm 9.1$ & $61.3 \pm 7.1$ & $89.5 \pm 17.1^{\mathrm{a}}$ \\
Urea (mg/dl) & $43.0 \pm 1.3$ & $57.3 \pm 2.4$ & $53.3 \pm 6.5$ & $50.6 \pm 3.6$ \\
Creatinine (mg/dl) & $0.4 \pm 0.08$ & $0.6 \pm 0.08$ & $0.6 \pm 0.03$ & $0.4 \pm 0.09$ \\
\hline
\end{tabular}

Data are expressed as mean \pm SEM from ten animals/group analyzed by ANOVA followed by Tukey test.

${ }^{a}$ Significantly different from control group $(p<0.05)$.

Table 6. Effects of ZBEE on biochemical and hematological parameters of peripheral blood of female mice subjected to repeated dose ( 28 days. v.o.).

\begin{tabular}{|c|c|c|c|c|}
\hline \multirow{2}{*}{ Parameters } & \multirow{2}{*}{ Control } & \multicolumn{3}{|c|}{ ZBEE (mg/kg) } \\
\hline & & 250 & 500 & 1000 \\
\hline \multicolumn{5}{|l|}{ Female } \\
\hline $\operatorname{RBCs}\left(10^{6} / \mathrm{mm}^{3}\right)$ & $9.0 \pm 0.2$ & $8.6 \pm 0.4$ & $8.6 \pm 0.3$ & $9.1 \pm 0.1$ \\
\hline Hemoglobin (g/dl) & $14.4 \pm 0.4$ & $13.7 \pm 0.4$ & $13.5 \pm 0.4$ & $14.3 \pm 0.3$ \\
\hline Hematocrit (\%) & $51.1 \pm 1.4$ & $48.6 \pm 1.4$ & $47.0 \pm 1.5^{\mathrm{a}}$ & $51.1 \pm 1.5$ \\
\hline $\operatorname{VCM}\left(\mathrm{fm}^{3}\right)$ & $56.7 \pm 0.9$ & $56.8 \pm 1.6$ & $54.6 \pm 1.3$ & $56.3 \pm 1.2$ \\
\hline $\mathrm{HCM}(\mathrm{pg})$ & $16.0 \pm 0.3$ & $16.0 \pm 0.3$ & $15.7 \pm 0.2$ & $16.5 \pm 0.2$ \\
\hline $\mathrm{CHCM}(\mathrm{g} / \mathrm{dl})$ & $28.3 \pm 0.5$ & $28.3 \pm 0.4$ & $28.8 \pm 0.7$ & $28.0 \pm 0.4$ \\
\hline Total leukocytes $\left(10^{3} / \mathrm{mm}^{3}\right)$ & $3.6 \pm 0.2$ & $6.5 \pm 0.8$ & $6.0 \pm 0.6$ & $6.8 \pm 0.7$ \\
\hline Lymphocytes & $76.0 \pm 2.2$ & $78.4 \pm 4.9$ & $74.8 \pm 2.6$ & $79.6 \pm 1.4$ \\
\hline Neutrophils & $18.0 \pm 2.1$ & $16.9 \pm 4.7$ & $20.0 \pm 2.5$ & $18.4 \pm 1.1$ \\
\hline Monocytes & $4.1 \pm 0.4$ & $4.4 \pm 0.9$ & $3.4 \pm 0.4$ & $1.3 \pm 0.4^{\mathrm{a}}$ \\
\hline Eosinophils & $1.4 \pm 0.3$ & $0.8 \pm 0.3$ & $0.4 \pm 0.2^{\mathrm{a}}$ & $0.0 \pm 0.0^{\mathrm{a}}$ \\
\hline $\operatorname{AST}(\mathrm{U} / 1)$ & $164.7 \pm 10.6$ & $182.7 \pm 13.4$ & $180.1 \pm 16.7$ & $151.1 \pm 11.5$ \\
\hline ALT (U/1) & $24.2 \pm 2.4$ & $56.8 \pm 9.0^{\mathrm{a}}$ & $63.7 \pm 6.8^{\mathrm{a}}$ & $41.1 \pm 1.3^{\mathrm{a}}$ \\
\hline Urea (mg/dl) & $40.3 \pm 1.3$ & $46.5 \pm 6.7$ & $50.9 \pm 7.1$ & $43.3 \pm 3.3$ \\
\hline Creatinine (mg/dl) & $0.6 \pm 0.05$ & $0.2 \pm 0.05^{\mathrm{a}}$ & $0.2 \pm 0.02^{\mathrm{a}}$ & $0.2 \pm 0.03^{\mathrm{a}}$ \\
\hline
\end{tabular}

Data are expressed as mean \pm SEM from ten animals/group analyzed by ANOVA followed by Tukey test.

a Significantly different from control group $(p<0.05)$.

evaluation of chemicals faces to animal welfare and in vitro systems are more welcome than the in vivo systems, the in vivo test systems are paid more attention in the field of genotoxicity because of its weight of evidence (Hayashi, 2016). Herein, ZBEE $(2,000 \mathrm{mg} / \mathrm{kg})$ did not alter the number of micronucleated erythrocytes in peripheral blood $(7.83 \pm 0.75)$, comparing to the control group $(8.33 \pm 0.99)$, suggesting no genotoxicity
(Table 7). In contrast, literature data have shown genotoxic effects for other Zornia species, for example, Zornia diphylla (Belcavello et al., 2012).

There are few literature reports about toxicological and pharmacological properties of Zornia species (Arunkumar et al., 2012a, 2012b, 2014; Laxane et al., 2008, 2011; Rojas et al., 1999; Sawant et al., 2014; Talluri et al., 2018). In addition, 

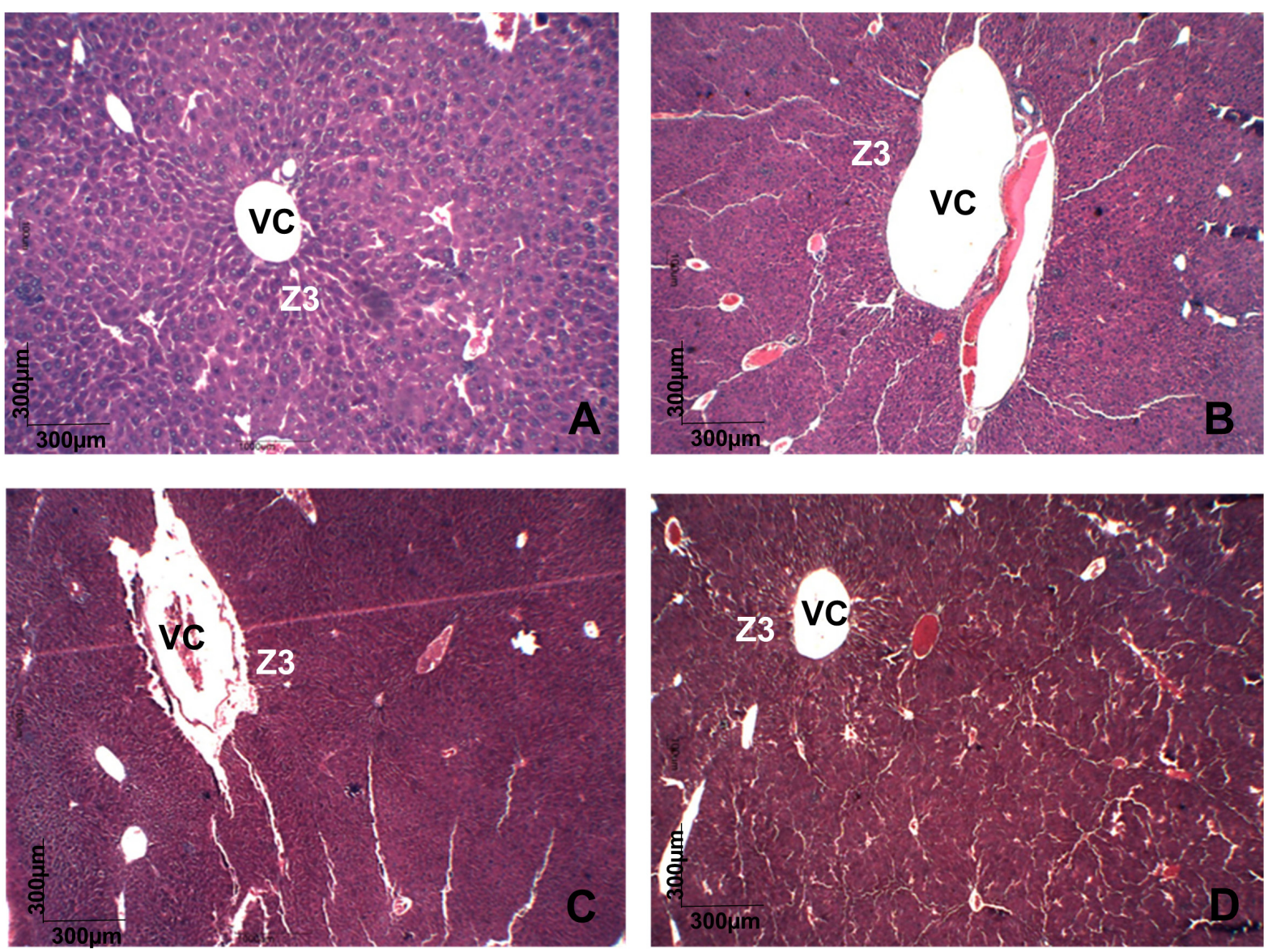

Figure 2. Histopathology of liver of different groups stained with Masson's trichrome. All groups showing a normal histological picture of terminal hepatic venule $(\mathrm{VC})$ surrounded in zone $3(\mathrm{Z3})$ of the hepatocyte acinus showed no changes in cell size or connective tissue. (A) cControl male mice. (B) cControl female mice. (C) ZBEE 1,000 mg/kg male mice. (D) ZBEE 1,000 mg $/ \mathrm{kg}$ female mice. VC=: hepatic venule; $\mathrm{Z} 3=$ : zone 3 .

Table 7. Effect of ZBEE on micronucleated erythrocytes number in peripheral blood of mice subjected to a single-dose ZBEE or cyclophosphamide.

\begin{tabular}{lcc}
\hline Groups & Dose $(\mathbf{m g} / \mathbf{k g})$ & Number of micronucleated erythrocytes \\
\hline Control & - & $8.33 \pm 0.99$ \\
Cyclophosphamide & 50 & $17.67 \pm 1.39^{\mathrm{a}}$ \\
ZBEE & 2,000 & $7.83 \pm 0.75$ \\
\hline
\end{tabular}

Data are expressed as mean \pm SEM from six animals/gender/group analyzed by ANOVA followed by Tukey test.

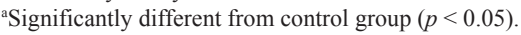

these species are widely used in the folk medicine (Arunkumar et al., 2014; Laxane et al., 2011; Sawant et al., 2014). Despite this, only one toxicological study for Zornia species has been described (Arunkumar et al., 2012b). Therefore, data presented in the present study for $Z$. brasiliensis contribute to the knowledge of the Zornia genus toxicological profile, as well as to the safe use in the folk medicine.

\section{CONCLUSION}

Zornia brasiliensis has weak toxicity after treatment of single or repeated doses, providing data for its safe use in the folk medicine and encouraging further pharmacological studies with this medicinal plant.

\section{AUTHORS' CCONTRIBUTIONS}

Tatianne Batista, Renata Abrantes, Aline Xavier, João Carlos Pita, Monalisa Brito, Adriano Alves, Anne Dayse Silva, Yuri Nascimento, Sócrates Santos, Josean Tavares, Marcelo Silva, and Marianna Sobral contributed to the conception or design of the work or the acquisition, analysis, or interpretation of data for the work; drafting the work or revising it critically for important intellectual content; final approval of the version to be published; agreement to be accountable for all aspects of the work in ensuring that questions related to the accuracy or integrity of any part of the work are appropriately investigated and resolved.

\section{ACKNOWLEDGMENTS}

The Coordenação de Aperfeiçoamento de Pessoal de Nível Superior-Brasil (CAPES) financed part of the study (Finance Code 001and CNPq).

\section{FUNDING}

The Coordenação de Aperfeiçoamento de Pessoal de Nível Superior-Brasil (CAPES) financed part of the study (Finance Code 001 and $\mathrm{CNPq}$ ). 


\section{CONFLICTS OF INTEREST}

The authors report no financial or any other conflicts of interest in this work.

\section{ETHICAL APPROVALS}

All the study was approved by the Animal Ethics Committee of the Federal UEPB in December 2015 (CEUA/ UFPB number 0701/14).

\section{PUBLISHER'S NOTE}

This journal remains neutral with regard to jurisdictional claims in published institutional affiliation.

\section{REFERENCES}

Agra MF, Silva KN, Basílio IJLD, Freitas PF, Barbosa-Filho JM. Survey of medicinal plants used in the region Northeast of Brazil. Braz J Pharmacogn, 2008; 18:472-508.

Araldi RP, de-Melo TC, Mendes TB, Sá-Júnior PL, Nozima BHN, Ito ET, Cassia SR. Using the comet and micronucleus assays for genotoxicity studies: a review. Biomed Pharmacother, 2015; 72:74-82.

Arunkumar R, Nair SA, Rameshkumar KB, Subramoniam A. The essential oil constituents of Zornia diphylla (L.) Pers, and antiinflammatory and antimicrobial activities of the oil. Rec Nat Prod, 2014; 8:385-93

Arunkumar R, Nair SA, Subramoniam A. Effectiveness of Zornia diphylla (L.) Pers, against fungal diseases. Ann Phytomed, 2012a; $1: 81-9$.

Arunkumar R, Nair SA, Subramoniam A. Induction of cell specific apoptosis and protection of mice from cancer challenge by a steroid positive compound from Zornia diphylla (L.) Pers. J Pharmacol Pharmacother, 2012b; 3:233-41.

Belcavello L, Cunha MRH, Andrade MA, Batitucci MCP. Cytotoxicity and DNA damages induced by the Zornia diphylla extract, a medicinal plant. Natureza, 2012; 10:140-5.

ANVISA. Brazil, Ministry of Health. National Health Surveillance Agency. Guide for conducting non-clinical studies of toxicology and safety pharmacology required to drug development (Version 2). Management of Safety and Efficacy Assessment - GESEF. Ministry of Health, Brasília, Brazil, 2013

Costa EV, Menezes LRA, Rocha SL, Baliza IRS, Dias RB, Rocha CAG, Soares MBP, Bezerra DP. Antitumor properties of the leaf essential oil of Zornia brasiliensis. Planta Med, 2015; 81:563-7.

Da Silva ADS, Cavalcante-Silva LHA, Da Matta CBB, Silva DDF, Araújo MVD, Tavares JF, Alexandre-Moreira MS. Antinociceptive effect of 7-methoxyflavone isolated from Zornia brasiliensis. Nat Prod Res, $2013 ; 27: 1695-9$.

Da Silva ARH, Lopes LQS, Cassanego GB, De Jesus PR, Figueredo KC, Santos RCV, Lopes GHH, Bauermann LF. Acute toxicity and antimicrobial activity of leaf tincture Baccharis trimera (Less). Biomed J, 2018; 41:194-201.

David JP, Meira M, David JM, Brandão HN, Branco A, Agra MF, Barbosa MR, De Queiroz LP, Giulietti AM. Radical scavenging, antioxidant and cytotoxic activity of Brazilian caatinga plants. Fitoterapia, 2007; 78:215-8.

Diehl KH, Hull R, Morton D, Pfister R, Rabemampianina Y, Smith D, Vidal JM, Vorstenbosch CVD. A good practice guide to the administration of substances and removal of blood, including routes and volumes. J Appl Toxicol, 2001; 21:15-23.

Dos Santos-Júnior HM, Oliveira DF, de-Carvalho DA, Pinto JMA, Campos VAC, Mourão ARB, Pessoa C, Moraes MO, Costa-Lotufo
LV. Evaluation of native and exotic Brazilian plants for anticancer activity J Nat Med, 2010; 64:231-8.

Gad SC. Animal models in toxicology. 2nd edition, CRC Press, Boca Raton, Florida, 2007.

Hayashi $\mathrm{M}$. The micronucleus test-most widely used in vivo genotoxicity test. Genes Environ, 2016; 38:18-24.

Kahaliw W, Hellman B, Engidawork E. Genotoxicity study of ethiopian medicinal plant extracts on HepG2 cells. BMC Complement Altern Med, 2018; 18:45-53.

Kang C, Munawir A, Cha M, Sohn ET, Lee H, Kim JS, Yoon DW, Lim D, Kim E. Cytotoxicity and hemolytic activity of jellyfish Nemopilema nomurai (Scyphozoa: Rhizostomeae) venom. Comp Biochem Physiol C Toxicol Pharmacol, 2009; 150:85-90.

Laxane SN, Swarnkar SK, Setty MM. Antioxidant studies on the ethanolic extract of Zornia gibbosa. Pharmacology, 2008; 1:319-30.

Laxane SN, Swarnkar SK, Zanwar SB, Setty MM. Antiinflammatory studies of the alcoholic extract of Zornia gibbosa. Pharmacology, 2011; 1:67-76.

Miyanishi K, Choudhury ME, Watanabe M, Kubo M, Nomoto M, Yano H, Tanaka J. Behavioral tests predicting striatal dopamine level in a rat hemi-Parkinson's disease model. Neurochem Int, 2019; 122:38-46.

Nascimento YM, Abreu LS, Lima RL, Costa VCO, Melo JIM, Braz-Filho R, Silva MS, Tavares JF. Rapid characterization of triterpene saponins from Zornia brasiliensis by HPLC-ESI-MS/MS. Molecules, 2019; 24:2519-33.

Nascimento YM, Abreu LS, Lima RL, Silva ADS, Costa VCO, Melo JIM, Scotti MT, Sobral MV, Araújo SS, Filho MAG, Silva MS, Tavares JF. Zornioside, a dihydrochalcone C-glycoside, and other compounds from Zornia brasiliensis. Rev Bras Farmacogn, 2018; 28:192-7.

OECD. Test No. 407: repeated dose 28-day oral toxicity study in rodents, OECD guidelines for the testing of chemicals, Section 4, OECD Publishing, Paris, France, 2008. Available via https://doi org/10.1787/9789264070684-en (accessed 17 October 2019).

OECD. Test No. 474: Mammalian erythrocyte micronucleus test, OECD guidelines for the testing of chemicals, Section 4, OECD Publishing, Paris, France, 2016. Available via https://doi.org/10.1787/9789264264762en (accessed 17 October 2019).

Pagano M, Faggio C. The use of erythrocyte fragility to assess xenobiotic cytotoxicity. Cell Biochem Funct, 2015; 33:351-5.

Prut L, Belzung C. The open field as a paradigm to measure the effects of drugs on anxiety-like behaviors: a review. Eur J Pharmacol, 2003; 463:3-33.

Rojas A, Bah M, Rojas JI, Serrano V, Pacheco S. Spasmolytic activity of some plants used by the Otomi Indians of Queretaro (Mexico) for the treatment of gastrointestinal disorders. Phytomedicine, 1999; 6:367-71.

Sawant B, Bairy T, Acharya S. Analgesic activity and acute toxicity study of Zornia gibbosa span (Samyojaki) in mice. Res Rev A J Pharmacol, 2014; 4:1-4.

Talluri MR, Tadi RS, Battu GR, Zubair M. The glucose lowering effect of Zornia gibbosa span extracts in diabetic rats. Turk J Pharm Sci, $2018 ; 15: 339-46$

How to cite this article:

Batista T, Abrantes R, Xavier A, Pita JC, Brito M, Alves A, Dayse A, Nascimento Y, Santos S, Tavares J, Silva M, Sobral M. Non-clinical toxicological evaluation of the ethanolic extract from Zornia brasiliensis vogel (fabaceae). J Appl Pharm Sci, 2021; 11(04):068-075. 